\title{
Analisis Fraud Pentagon Terhadap Kecurangan Laporan Keuangan Pada Sektor Perusahaan Manufaktur
}

\author{
Delviana Dama Yanti ${ }^{{ }^{*}}$ Munari $^{2}$ \\ ${ }^{1)}$ Universitas Pembangunan Nasional Veteran Jawa Timur, Indonesia, delviana.damayanti@gmail.com. \\ ${ }^{2)}$ Universitas Pembangunan Nasional Veteran Jawa Timur, Indonesia
}

\section{ARTICLE INFO}

\section{Article history:}

Received 26 Maret 2021

Received in Revised 19 April 2021

Accepted 29 April 2021

\section{Keywords:}

Financial Statement Fraud,

Manufacturing Companies, Pentagon Fraud

\section{A B S T R A C T}

The purpose of this research is to see the effect of pentagon fraud that proxied by financial targets, nature of the industry, quality of external auditors, change of auditors, number of CEOs who frequently detect fraud in financial statements. Financial statement fraud in this study was measured using the proxies of Return on Assets, Receivables, selection of audit services at public accounting firms, changes in public accounting firms, changes in directors, and the number of CEO photos. The population in research study are use manufacturing companies who listed on the Indonesia Stock Exchange (BEI) in 2017-2019. This research uses a purposive sampling technique so, there are 48 financial reports from 25 manufacturing companies. The analytical method used in this research is multiple linear regression analysis with SPSS version 20. The results of this research indicate that financial targets, nature of industry, quality of external auditors and the number of CEOs who often don't have a significant effect in the handling of fraudulent financial statements. Meanwhile, changes in auditors and changes in direction have a significant effect from pentagon fraud side on fraudulent financial statements.

Tujuan penelitian ini adalah untuk melihat pengaruh fraud pentagon yang di proksikan dengan financial target, nature of industry, quality of external auditor, change of auditor, frequent number of CEO terhadap pendeteksian kecurangan (fraud) laporan keuangan. Kecurangan dalam Laporan Keuangan di penelitian ini diukur menggunakan proksi Return on Assets, Receivable, pemilihan jasa audit pada $\mathrm{KAP}$, pergantian KAP, perubahan direksi, dan banyaknya foto CEO. Perusahaan manufaktur yang terdaftar di Bursa Efek Indonesia (BEI) pada tahun 2017-2019 digunakan sebagai populasi dalam penelitian ini. Penelitian ini menggunakan teknik purposive sampling sehingga terdapat 48 laporan keuangan dari 25 perusahaan manufaktur. Analisis regresi linear berganda merupakan metode analisis yang digunakan dengan SPSS versi 20. Financial target, nature of industry, quality of external auditor dan frequent number of CEO tidak bepengaruh signfikan dalam mendeteksi adanya kecurangan dalam Laporan Keuangan dalam penelitian ini. Sedangkan, change of auditor dan change of direction berpengaruh signifikan dalam medeteksi kecurangan dalam laporan keuangan.

AKUISISI : Jurnal Akuntansi

Website : http://www.fe.ummetro.ac.id/ejournal/index.php/JA

This is an open access article distributed under the terms of the Creative Commons Attribution 4.0 International License, which permits unrestricted use, distribution, and reproduction in any medium, provided the original work is properly cited.

* Corresponding author. Tel.: +62821-7946-6131; fax: +0-000-000-0000

E-mail address: delviana.damayanti@gmail.com

Peer review under responsibility of Akuisisi : Accounting Journal. 2477-2984. 


\section{PENDAHULUAN}

Dari beberapa bentuk alat komunikasi yang dimiliki perusahaan, salah satunya adalah annual report yang berisi data dan aktivitas operasional serta kondisi keuangan perusahaan selama periode tertentu yang dijadikan sebagai tolak ukur efesiensi dan efektifitas kinerja suatu perusahaan bagi para pemangku kepentingan (stakeholder). Perusahaan harus menyajikan laporan keuangan secara maksimal dan akurat sesuai dengan unsur kualitatif yang meliputi relevan, andal, serta dapat dipahami, dapat dibandingkan. Hal ini bertujuan agar meminimalisir adanya tindak kejahatan berupa kecurangan dalam laporan keuangan dan informasi yang diberikan dapat dipercaya serta tidak merugikan pihak yang berkepentingan dalam penentuan suatu keputusan.

Saat ini, di dalam dunia bisnis seluruh perusahaan bersaing untuk mengembangkan perusahaan yang dimiliki. Agar mampu bertahan dalam persaingan dunia bisnis, salah satu usaha untuk menghadapi persaingan tersebut adalah melakukan praktik kecurangan dengan cara menyajikan laporan keuangan yang tidak relevan serta tidak akurat melalui rekayasa nilai material atau yang sering disebut dengan Financial Statement Fraud. Agustina \& Pratomo (2019) menyatakan karena laporan keuangan sangat penting bagi perusahaan, manajemen dapat menutupi keadaan sebenarnya yang terjadi dalam laporan keuangan melalui cara melakukan kecurangan dalam laporan keuangan dengan tujuan kinerja yang terlihat positif.

Berdasarkan hasil Survei Fraud Indonesia pada tahun 2019, Korupsi menjadi kasus fraud yang tertinggi terjadi di negara Indonesia dengan persentase sebesar 64,4\%. Penyalahgunaan Aset atau Kekayaan Negara dan Perusahan menduduki posisi kedua dalam kasus fraud yang terjadi di Indonesia Perusahan dengan persentase sebesar 28, 9\%. Dan kasus fraud yang jarang terjadi Indonesia adalah Fraud Laporan Keuangan dengan persentase hanya 6,7\%. Hal ini disebabkan karena kasus korupsi lebih sering disorot oleh media sehingga masyarakat menilai bahwa skandal korupsi sebagai kasus fraud yang baling banyak di Indonesia. Namun, jika ditinjau dari segi besarnya kerugian akibat terjadinya fraud, Fraud Laporan Keuangan menempati posisi pertama dengan persentase 67,4\% dengan nilai kerugian dibawah Rp. 10.000.000,- dan memiliki persentase sebesar 5,0\% dengan nilai kerugian lebih dari 10 milyar. 
Tabel 1 Nilai kerugian akibat fraud paling merugikan di Indonesia

\begin{tabular}{|l|c|c|c|}
\hline NILAI KERUGIAN & Korupsi & $\begin{array}{c}\text { Fraud } \\
\text { Laporan Keuangan }\end{array}$ & $\begin{array}{c}\text { Penyalahgunaan } \\
\text { Aset/Kekayaan } \\
\text { Negara \& Perusahaan }\end{array}$ \\
\hline Rp. $\leq 10$ Juta & $48,7 \%$ & $67,4 \%$ & $63,6 \%$ \\
\hline Rp.10 Juta - 50 Juta & $4,2 \%$ & $2,9 \%$ & $3,3 \%$ \\
\hline Rp.50 Juta - 100 Juta & $8,4 \%$ & $5,4 \%$ & $8,8 \%$ \\
\hline Rp.100 Juta - 500 Juta & $11,7 \%$ & $6,7 \%$ & $9,6 \%$ \\
\hline Rp.500 Juta - 1 Milyar & $10,9 \%$ & $6,7 \%$ & $2,9 \%$ \\
\hline Rp.1 Milyar - 5 Milyar & $5,9 \%$ & $3,8 \%$ & $3,8 \%$ \\
\hline Rp.5 Milyar - 10 Milyar & $5,4 \%$ & $2,7 \%$ & $3,4 \%$ \\
\hline Rp. >10 Milyar & $5,4 \%$ & $5,0 \%$ & $4,6 \%$ \\
\hline
\end{tabular}

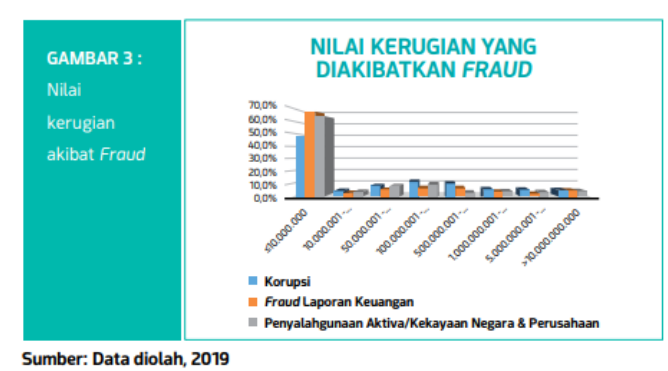

Perusahaan manufaktur memiliki tanggung jawab yang tidak terbatas berarti bahwa kekayaan pribadi pemilik perusahaan juga dapat dijadikan jaminan terhadap seluruh hutang perusahaan. Selain itu, perusahaan manufaktur memiliki risiko yang berkaitan dengan kewajiban perusahaan karena pendanaan ebrasal dari luar perusahaan sehingga peluang terjadinya financial statement fraud sangat besar.

Siddiq \& Suseno (2019) mengatakan perkembangan teori yang mempengaruhi risiko dalam keuangan yang berawal dari Cressey yang menciptakan teori tersebut (1953) menjadi teori yang diciptakan Crowe (2010). Menurut Donald R. Cressey fraud triangle yang terdiri dari tekanan (Pressure), peluang (Opportunity), rasionalisasi (Rationalization) merupakan tiga elemen pendorong seseorang untuk melakukan kecurangan. Dengan membubuhkan elemen kemampuan atau capability yang dilakukan oleh Wolfe \& Hermason pada tahun 2004 fraud pentagon berkembang membentuk fraud diamond. Crowe (2010) mengembangkan menjadi teori fraud pentagon dengan menambahkan elemen Arogansi (Arrogance) karena toeri yang sebelumnya dianggap belum dapat digunakan dalam segala kondisi.

Berdasarkan latar belakang tersebut, financial target (ROA) digunakan sebagai proksi dari variabel tekanan. Nature of industry (RECEIVABLE) dan quality of external auditor sebagai proksi dari variabel peluang. Change of auditor sebagai proksi dari variabel rasionalisasi. Change of director sebagai proksi dari variabel kemampuan. Dan frequent number of CEO sebagai pengukur variabel arogansi.

\section{TINJAUAN PUSTAKA}

Teori keagenan yang didefinisikan oleh Jansen and Meckling menyatakan jika salah satu pihak (principal) seperti owner perusahaan dan pemilik saham mewakilkan otoritasnya dalam membuat keputusan atau melakukan suatu pekerjaan kepada pihak lain (agent) seperti manajemen maka disebut 
hubungan agensi. Maksud dari teori keagenan ini ialah adanya hubungan kerjasama pihak principal seperti pemegang saham yang memiliki keinginan serta akses untuk mendapatkan informasi yang memiliki kerterkaitan dengan perusahaan tempat mereka berinvestasi. Dan manajemen sebagai agent selaku pelaku nyata dalam kegiatan operasional yang dilakukan oleh perusahaan, pasti mengetahui secara menyeluruh mengenai informasi-informasi yang berhubungan dengan kegiatan operasi hingga kinerja perusahaan.

Memperoleh keuntungan yang tinggi atas kegiatan investasinya pada suatu perusahaan merupakan tujuan utama principal. Principal memiliki tujuan untuk selalu mendapatkan return yang tinggi atas invetasi yang dikeluarkan untuk perusahaan tersebut. Sedangkan, agent memiliki tujuan tersendiri untuk mendapatkan kompensasi atau hasil yang memuaskan atas kinerjanya. Hal tersebut menunjukkan bahwa terdapat benturan keperluan atau conflict of interest dari pihak principal dengan agent . Akibat dari adanya konflik kepentingan tersebut, menumbuhkan sikap saling tidak percaya dikarenakan agent bertindak untuk kepentingan pribadinya sehingga tidak sesuai dengan kepentingan yang diperlukan oleh principal. Dari adanya konflik tersebut, akan memancing timbulnya kecurangan.

Didalam Aprilia (2017) Eisenhardt menggolongkan tiga jenis sifat dasar manusia yang menimbulkan kecurangan yaitu pada dasarnya manusia mementingkan pribadinya (self interest), keterbatasan daya pikir manusia tentang pandangan masa depan (bounded rationality), dan cenderung menghindari adanya risiko yang biasa disebut risk averse. Self interest berhubungan dengan faktor Tekanan, kemampuan, dan arogansi berhubungan dengan kepentingan pribadi atau self interest. Peluang dan rasionalisasi berhubungan dengan menghindar dari risiko atau risk averse.

Bawekes et al., (2018) menjelaskan bahwa ACFE mendefinisikan kecurangan laporan merupakan kesengajaan penyampaian yang salah mengenai kondisi keuangan perusahaan karena perhitungan jumlah yang salah atau lalai dalam mengungkapkan laporan keuangan dengan tujuan memperdaya para stakeholders. Pemalsuan, manipulasi, perubahan catatan akuntansi dan data pendukung yang disajikan dengan salah serta sengaja melenyapkan informasi dan transaksi penting dari laporan keuangan termasuk kedalam kegiatan kecurangan laporan keuangan.

Fraud Pentagon adalah teori terbarukan mengenai faktor pemicu fraud untuk memperluas fraud triangle dan fraud diamond. Crowe Howarth mengemukakan teori tersebut pada tahun 2011 dengan menambahkan elemen arogansi (arrogance). Sehingga, elemen pemicu seseorang melakukan kecurangan dari sisi fraud pentagon adalah tekanan atau pressure, peluang atau opportunity, rasionalisasi atau rationalization, kemampuan atau capability, dan arogansi atau arrogance. Howarth didalam Pratiwi \& Nurbaiti (2018) menyatakan sifat kekuasaan atas wewenang dan menganggap kebijakan dan pengendalian internal perusahaan tidak berlaku bagi dirinya disebut arogansi.

Tekanan bisa terjadi dari pihak eksternal dan internal. Ketika perusahaan mendapatan tekanan tidak stabil dalam keuangannya, maka memungkinkan perusahaan melakukan kecurangan laporan 
keuangan. Hery (2016:200) menjelaskan motivasi seseorang untuk melakukan manipulasi laporan keuangan muncul pada saat adanya penurunan atau tidak stabilnya entitas keuangan karena kondisi industri, hingga ekonomi disebut tekanan. Variabel proksi pertama dari tekanan (pressure) adalah Financial Target. Menurut SAS No.99 di dalam Setiawati \& Baningrum (2018), sebuah risiko yang muncul karena tekanan besar untuk manajemen dalam mendapatkan target laba berdasarkan pada peraturan manajemen hingga direksi contohnya insentif srta penentuan bonus nantinya didapkan oleh para karyawan disebut financial target. Keterkaitan antara kinerja perusahaan dengan financial target dapat digunakan untuk mengukur atau menilai prosentase laba yang diperoleh suatu perusahaan berdasarkan usahanya.

Pada umumnya, Return On Assets (ROA) digunakan untuk memperkirakan financial target umumnya yang berupa laba. Lestari \& Henny (2019) menjelaskan bahwa ROA menurut Skousen (2008) merupakan efisiensi aset yang digunakan dalam mendapatkan laba melaui cara mengkomparasikan laba yang diperoleh dengan jumlah aktiva yang diperoleh perusahaan sebagai ukuran kinerja operasional perusahaan secara umum. Jika perusahaan menghasilkan ROA yang bertambah tinggi pada setiap periode, kinerja perusahaan dianggap semakin baik untuk penggunaan assets nya untu menghasilkan laba. Semakin besar nilai financial target akan memicu untuk melakukan manipulasi atau kecurangan dalam laporan perusahaan.

Faradiza (2018) dan Agusputri \& Sofie (2019) menjelaskan jika Financial Target yang diproksikan dengan Return On Assets (ROA) memiliki pengaruh terhadap terjadinya kecurangan laporan keuangan. Sehingga hipotesis dari variabel tekanan adalah:

\section{$\mathrm{H}_{1}$ : Financial Target berpengaruh signifikan terhadap terjadinya kecurangan dalam laporan keuangan.}

Variable proksi pertama dari elemen peluang (opportunity) adalah sifat industri (nature of industry). Lemahnya dalam pengendalian internal, tidak efektifnya pengawasan yang dilakukan direksi serta adanya penyelewengan otoritas dan posisi memunculkan peluang (Wahyuni \& Budiwitjaksono, 2017). Nature of industry adalah kondisi ideal yang dimiliki perusahaan pada kegiatan industry. Perusahaan dapat dikatakan ideal jika menghasilkan sebuah keuntungan. Dengan adanya keuntungan dapat menarik para investor untuk menananamkan modal yang dimilikinya pada perusahaan tersebut. Hal tersebut bisa membuat pihak manajemen melakukan tindakan kecurangan dalam laporan keuangan agar perusahaannya terlihat baik dan ideal (Agusputri \& Sofie, 2019). Apabila suatu perusahaan mampu memperkecil atau mempunyai total piutang yang kecil serta perusahaan mampu meningkatkan kas yang dimilikinya maka perusahaan tersebut dikategorikan baik (Sasongko \& Wijayantika, 2019). Besarnya saldo pada akun-akun khusus seperti akun persediaan using dan akun piutang tak tertagih dalam laporan keuangan dapat ditentukan oleh perusahaan berdasarkan estimasi. Annisya et al., (2016) menyatakan bahwa manajemen memungkinkan melakukan manipulasi seperti penyelewengan umur eknomis aset berdasarkan estimasi penilaian seperti piutang tidak tertagih maupun simpanan sudah 
usang.

Faradiza (2018) menguji tentang pengaruh nature of industry terhadap kecurangan dalam laporan keuangan dan hasil dari penelitian tersebut nature of industry yang diukur menggunakan rasio perubahan pada piutang usaha memberikan dampak yang signifikan terhadap kecurangan laporan keuangan. Sehingga hipotesis dari penelitian ini adalah

\section{$\mathrm{H}_{2}$ : Nature of industry berpengaruh signifikan terhadap terjadinya kecurangan laporan}

\section{keuangan.}

Variabel proksi kedua dari elemen peluang (opportunity) adalah quality of external auditor. De Angelo (1981) didalam R. Siddiq et al., (2017) berpendapat jika probabilitas dari auditor eksternal adalah kualitas dalam audit dalam melakukan deteksi dan pelaporan hasil audit yang dilakukannya. Karena adanya pengaruh kualitas auditor eksternal dalam aktivitas audit, maka dibutuhkan auditor eksternal yang mempunyai kemampuan dan keahlian memadai dalam melakukan audit laporan keuangan

Kualitas auditor eskternal dapat ditentukan dengan cara membedakan pemilihan kantor akuntan public (KAP) yang tergabung dalam BIG 4 yang terdiri dari PwC, EY, Deloitte, dan KPMG dengan yang tidak masuk kedalam katogori BIG 4. Bawekes et al. (2018) menunjukkan penelitian Lennox \& Pittman (2010) yaitu auditor eksternal yang berkiprah di KAP yang masuk dalam kategori BIG 4 mempunyai capability lebih dalam melakukan deteksi kecurangan jika dibandingkan dengan auditor eksternal yang bekerja pada KAP non-BIG 4. Penggunaan KAP BIG 4 mendapatkan peluang besar dalam pendeteksian kecurangan laporan keuangan, dibandingkan dengan KAP non-BIG 4. Hal ini dikarenakan hasil audit yang dilakukan KAP kategori BIG 4 dipandang lebih memiliki capability dan ahli menerbitkan laporan keuangan lebih berbobot Setiawati \& Baningrum (2018). Penelitian Bawekes et al., (2018) menunjukkan jika kualitas auditor eksternal tidak berpengaruh kepada kecurangan laporan keuangan. Sehingga, hipotesis dari penelitian ini adalah:

\section{$\mathrm{H}_{3}$ : Quality Of External Auditor berpengaruh signifikan terhadap terjadinya kecurangan} dalam laporan keuangan.

Variabel proksi dari elemen rasionalisasi (rationalization) adalah change of auditor atau pergantian auditor. Priantara (2013:27) mengatakan bahwa pembenaran dari kegiatan yang mengarah kedalam fraud dan pelaku menganggap jika kegiatannya tidak termasuk fraud bahkan menganggap bahwa hal tersebut adalah haknya bahkan merasa berjasa disebut rasionalisasi. SAS No.99 menyebutkan bahwa dugaan terjadinya kecurangan atau fraud dapat dinilai dari adanya pengaruh pergantian auditor.

Tessa \& Harto (2016) menyatakan menghapus fraud trail yang diketahui auditor sebelumnya merupakan salah satu bentuk fraud yang digunakan perusahaan melalui pergantian auditor. Hal tersebut mendorong perusahaan mengganti auditor independen bertujuan untuk merahasiakan kegiatan 
fraud dalam perusahaan.

Septriyani \& Handayani (2018) dan Pratiwi \& Nurbaiti (2018) belum menunjukkan hasil yang signifikan mengenai pengaruh penggantian auditor terhadap kecurangan laporan keuangan. Maka, hipotesis dari penelitian ini adalah:

\section{$\mathrm{H}_{4}$ : Change Of Auditor berpengaruh signifikan terhadap terjadinya kecurangan dalam}

\section{laporan keuangan}

Variabel proksi dari elemen kemampuan (capability) adalah perubahan direksi (change of direction). Faktor penunjang terjadinya fraud bisa disebabkan adanya perubahan direksi karena manajemen berupaya melakukan perbaikan kinerja direksi sebelumnya melalui cara perubahan sturctur organization atau anggapan bahwa direksi baru memiliki kemampuan lebih.

Elviani et al., (2020) menunjukkan pergantian direksi tidak berpengaruh terhadap terjadinya kecurangan laporan keuangan. Sedangkan Bayagub et al., (2018) menunjukkan pergantian direksi memberikan pengaruh terhadap terjadinya kecurangan laporan keuangan. Maka, hipotesis dari penelitian ini adalah:

$\mathrm{H}_{5}$ : Change of Direction berpengaruh signifikan terhadap terjadinya kecurangan dalam laporan keuangan.

Variabel proksi dari elemen arogansi adalah Frequent Number Of CEO atau jumlah foto Chief Executive Officer (CEO) yang terpampang didalam annual report atau laporan keuangan tahunan suatu perusahaan. Tingkat superioritas dan arogansi yang dimiliki CEO dapat dilihat melalui banyaknya foto CEO yang muncul dalam sebuah laporan keuangan karena CEO umumnya lebih ingin menunjukkan kepada publik akan posisi dan status yang dimilikinya dalam sebuah perusahaan karena tidak ingin kehilangan hal tersebut. Tingkat arogansi yang tinggi dapat menimbulkan terjadinya fraud karena arogansi yang dimiliki CEO dapat membuatnya menggunakan cara apapun untuk mempertahankan posisi dan status dimilikinya.

R. Siddiq et al., (2017) memperoleh hasil bahwa Frequent Number Of CEO berpengaruh terhadap terjadinya kecurangan laporan keuangan. Dan dari penjelasan diatas, diperoleh hipotesis:

$\mathrm{H}_{6}$ : Frequent Number $\mathrm{Of} \mathrm{CEO}$ berpengaruh signifikan terhadap terjadinya kecurangan dalam laporan keuangan

\section{METODE PENELITIAN}

Penelitan ini merupakan jenis penelitian kuantitatif dengan menganalisis data yang diperoleh. Populasi pada penelitian ini adalah perusahaan manufaktur yang terdaftar di Bursa Efek Indonesia (BEI) selama tahun 2017-2019 yang berjumlah 193 perusahaan dari 3 sub sektor perusahaan manufaktur. Teknik sampling dalam penelitaian ini adalah menggunakan teknik purposive sampling. 
Sugiyono (2017) mengatakan purposive sampling adalah teknik penentuan suatu sampel dengan pertimbangan tertentu. Pada penelitian ini dipilih perusahaan manufaktur yang terdaftar di BEI dari tahun 2017-2019 dengan kriteria sebagai berikut:

1. Perusahaan manufaktur yang terdaftar di Bursa Efek Indonesia pada tahun 2017-2019. (Total perusahaan manufaktur yang terdaftar di Bursa Efek Indonesia per tanggal 20 November 2020 adalah sebanyak 193 perusahaan).

2. Perusahaan manufaktur yang mulai tercatat di Bursa Efek Indonesia paling lama pada tahun 2016. (Jumlah perusahaan yang memenuhi kriteria ini adalah sebanyak 143 perusahaan).

3. Perusahaan yang mempublikasikan laporan tahunan atau annual report mulai dari tahun 2017-2019 yang sudah diaudit serta bisa diakses melalui website BEI dan website perusahan dan nominal dinyatakan dalam mata uang Rupiah. (Setelah memenuhi kriteria ini, total perusahaan yang memenuhi adalah sebanyak 103 perusahaan)

4. Data yang diperlukan terkait variabel-variabel yang digunakan pada penelitian ini tersedia dengan lengkap. (Perusahaan yang mempublikasikan data yang dibutuhkan oleh peneliti adalah sebanyak 80 perusahaan)

5. Laporan keuangan tahunan perusahaan yang mengalami kerugian dalam kurun waktu tahun 20172019.

Berdasarkan kriteria yang telah ditentukan, terdapat 25 perusahaan manufaktur yang terdaftar di Bursa Efek Indonesia dimana mengalami kerugian dalam kurun waktu 2017-2019. 25 perusahaan tersebut terbagi atas 10 perusahaan Basic Industry and Chemical, 10 perusahaan Consumer Goods Industry, dan 5 perusahaan Miscellaneous Industry. Dari perusahaan tersebut terdapat total 48 laporan keuangan yang mengalami kerugian.

\section{HASIL DAN PEMBAHASAN}

Tabel 2. Hasil Analisis Statistik Deskriptif

\begin{tabular}{|l|c|c|c|c|c|}
\hline \multicolumn{7}{|c|}{ Descriptive Statistics } \\
\hline ROA & $\mathrm{N}$ & Minimum & Maximum & Mean & Std. Deviation \\
\hline $\begin{array}{l}\text { RECEIVABLE } \\
\text { RATIO }\end{array}$ & 48 & -2.65 & .03 & -.1144 & .37927 \\
\hline $\begin{array}{l}\text { QUALITY } \\
\text { EXTERNAL } \\
\text { AUDITOR }\end{array}$ & 48 & -.20 & .22 & -.0035 & .07687 \\
\hline CHANGE AUDITOR & 48 & 0 & 1 & .25 & .438 \\
\hline $\begin{array}{l}\text { CHANGE } \\
\text { DIRECTOR }\end{array}$ & 48 & 0 & 1 & .25 & .438 \\
\hline CEO PIC & 48 & 1 & 15 & 5.23 & .501 \\
\hline F-SCORE & 48 & .07 & 4.45 & .7771 & .90924 \\
\hline Valid N (listwise) & 48 & & & & \\
\hline
\end{tabular}


Berdasarkan hasil tabel diatas, diperoleh informasi bahwa kecurangan pada laporan keuangan yang diproksikan dengan F-Score sebagai variabel dependen mempunyai rata-rata (mean) -0,7771 dengan standar deviasi 0,90924. Angka tersebut memiliki arti bahwa nilai F-Score normal perusahaan adalah -0,7771. Perusahaan yang memperoleh nilai F-Score yang cukup tinggi sebesar 4,45 dan perusahaan yang memperoleh nilai F-Score paling rendah adalah sebesar 0,07.

Selanjutnya, diperoleh informasi bahwa kecurangan pada laporan keuangan yang diproksikan dengan return on assets (ROA) sebagai variabel independen mempunyai rata-rata (mean) -0,1144 dengan standar deviasi 0,37927. Angka tersebut memiliki arti bahwa rata-rata keuntungan yang diperoleh perusahaan manufaktur pada periode penelitian adalah sebesar $-11,44 \%$. Perusahaan yang memiliki ROA cukup tinggi sebesar 3\% dan perusahaan yang memiliki ROA paling rendah sebesar $265 \%$.

Berdasarkan tabel 2 diperoleh informasi bahwa kecurangan pada laporan keuangan yang diproksikan dengan receivable ratio sebagai variabel independen mempunyai rata-rata (mean) -0,0035 dengan standar deviasi 0,07687. Angka tersebut memiliki arti bahwa rata-rata rasio piutang yang diperoleh perusahaan manufaktur pada periode penelitian adalah sebesar $-0,35 \%$. Perusahaan memiliki rasio piutang paling tinggi sebesar $22 \%$ sedangkan perusahaan yang memiliki rasio piutang paling rendah adalah sebesar $-20 \%$.

Berdasarkan tabel 2, dapat diperoleh informasi bahwa Frequent Number of CEO Picture yang di proksikan dengan jumlah foto CEO sebagai variabel independen mempunyai rata-rata 5,23 dengan standar deviasi 3,639. Angka tersebut memiliki arti bahwa rata-rata jumlah CEO pada perusahaan manufaktur pada periode penelitian adalah 5 orang. Perusahaan yang memiliki jumlah foto CEO dalam laporan keuangan paling banyak sebesar 15 dan perusahaan dengan jumlah foto CEO dalam laporan keuangan yang paling rendah sebesar 1 .

Tabel 3 Hasil Analisis Regresi Linear Berganda

\begin{tabular}{|c|c|c|c|c|c|c|}
\hline \multicolumn{7}{|c|}{ Coefficients $^{\mathbf{a}}$} \\
\hline & \multirow[t]{2}{*}{ Model } & \multicolumn{2}{|c|}{$\begin{array}{l}\text { Unstandardized } \\
\text { Coefficients }\end{array}$} & \multirow{2}{*}{$\begin{array}{c}\text { Standardized } \\
\text { Coefficients } \\
\text { Beta } \\
\end{array}$} & \multirow[t]{2}{*}{$\mathrm{t}$} & \multirow[t]{2}{*}{ Sig. } \\
\hline & & $\mathrm{B}$ & Std. Error & & & \\
\hline \multirow{7}{*}{1} & (Constant) & .403 & .277 & & 1.454 & .154 \\
\hline & $\mathrm{ROA}(\mathrm{X} 1)$ & -.981 & .354 & -.409 & -2.771 & .008 \\
\hline & $\begin{array}{l}\text { RECEIVABLE RATIO } \\
\text { (X2) }\end{array}$ & .305 & 1.634 & .026 & .187 & .853 \\
\hline & $\begin{array}{l}\text { QUALITY AUDITOR } \\
\text { (X3) }\end{array}$ & -.078 & .300 & -.037 & -.259 & .797 \\
\hline & $\begin{array}{l}\text { AUDITOR CHANGE } \\
(\mathrm{X} 4)\end{array}$ & .654 & .296 & .315 & 2.205 & .033 \\
\hline & $\begin{array}{l}\text { DIRECTION CHANGE } \\
\text { (X5) }\end{array}$ & .583 & .238 & .321 & 2.446 & .019 \\
\hline & CEO PIC (X6) & -.026 & .038 & -.104 & -.675 & .504 \\
\hline
\end{tabular}


Tabel 4 Hasil Uji Kolmogorov-Smirnov

\begin{tabular}{|c|c|c|}
\hline \multicolumn{3}{|c|}{ One-Sample Kolmogorov-Smirnov Test } \\
\hline & $\begin{array}{l}\text { Unstandardized } \\
\text { Residual }\end{array}$ \\
\hline \multicolumn{2}{|l|}{$\mathrm{N}$} & 48 \\
\hline \multirow{2}{*}{ Normal Parameters ${ }^{\mathrm{a}, \mathrm{b}}$} & Mean & 0E-7 \\
\hline & Std. Deviation & .72846392 \\
\hline \multirow{3}{*}{$\begin{array}{l}\text { Most Extreme } \\
\text { Differences }\end{array}$} & Absolute & .154 \\
\hline & Positive & .154 \\
\hline & Negative & -.111 \\
\hline \multicolumn{2}{|c|}{ Kolmogorov-Smirnov Z } & 1.067 \\
\hline \multicolumn{2}{|c|}{ Asymp. Sig. (2-tailed) } & .205 \\
\hline \multicolumn{3}{|c|}{ a. Test distribution is Normal. } \\
\hline
\end{tabular}

Tabel 5 Hasil Uji Multikolonearitas

\begin{tabular}{|c|c|c|c|}
\hline & \multirow[t]{2}{*}{ Model } & \multicolumn{2}{|c|}{$\begin{array}{l}\text { Collinearity } \\
\text { Statistics }\end{array}$} \\
\hline & & Tolerance & VIF \\
\hline & \multicolumn{3}{|l|}{ (Constant) } \\
\hline \multirow{6}{*}{1} & ROA (X1) & .719 & 1.391 \\
\hline & $\begin{array}{l}\text { RECEIVABLE RATIO } \\
(\mathrm{X} 2)\end{array}$ & .821 & 1.218 \\
\hline & $\begin{array}{l}\text { QUALITY AUDITOR } \\
\text { (X3) }\end{array}$ & .749 & 1.335 \\
\hline & $\begin{array}{l}\text { AUDITOR CHANGE } \\
\text { (X4) }\end{array}$ & .769 & 1.300 \\
\hline & $\begin{array}{l}\text { DIRECTION } \\
\text { CHANGE (X5) }\end{array}$ & 908 & 1.101 \\
\hline & CEO PIC (X6) & .663 & 1.509 \\
\hline
\end{tabular}

Tabel 6 Hasil Uji Autokolerasi

\begin{tabular}{|c|c|c|c|c|c|}
\hline $\begin{array}{c}\text { Mode } \\
1\end{array}$ & $\mathrm{R}$ & R Square & $\begin{array}{c}\text { Adjusted } \\
\text { R Square }\end{array}$ & $\begin{array}{c}\text { Std. Error of } \\
\text { the Estimate }\end{array}$ & $\begin{array}{c}\text { Durbin- } \\
\text { Watson }\end{array}$ \\
\hline 1 & $.598^{\mathrm{a}}$ & .358 & .264 & .77995 & 2.061 \\
\hline
\end{tabular}

a. Predictors: (Constant), CEO PIC (X6), DIRECTION CHANGE (X5), RECEIVABLE RATIO (X2), QUALITY AUDITOR (X3), AUDITOR CHANGE (X4), ROA (X1)

b. Dependent Variable: F-SCORE (Y)

Tabel 7 Hasil Uji F

\begin{tabular}{|l|c|c|c|c|cc|}
\hline \multicolumn{1}{|c|}{ ANodel $^{\text {Sum of }}$} & df & $\begin{array}{c}\text { Mean } \\
\text { Square }\end{array}$ & F & Sig. \\
\hline Regression & 13.915 & 6 & 2.319 & 3.812 & & \\
1 Residual & 24.941 & 41 & .608 & & & \\
Total & 38.856 & 47 & & & & \\
\hline \\
a. Dependent Variable: F-SCORE \\
b. Predictors: (Constant), CEO PIC, CHANGE DIRECTOR, RECEIVABLE RATIO , \\
QUALITY EXTERNAL AUDITOR, CHANGE AUDITOR, ROA \\
\hline
\end{tabular}


Hasil penelitian pada tabel 3 menunjukkan bahwa tingkat probabilitas yang tercipta pada return on asset lebih kecil daripada $\alpha 0,05$ yaitu sebesar 0,008 . Hasil diatas menyatakan jika H1 ditolak serta dapat disimpulkan bahwa financial target yang diproksikan dengan return on assets memiliki pengaruh negatif yang signifikan karena hasil penelitian menunjukkan $t_{\text {hitung }}-2,771>t_{\text {tabel }} 2,019$ pada tabel 2 hasil uji $\mathrm{T}$ namun berada pada daerah penolakan yang artinya berpengaruh tidak signifikan terhadap terjadinya kecurangan laporan keuangan. Hasil dari penelitian ini tidak sejalan dengan Faradiza (2018) dan Agusputri \& Sofie (2019). Penelitian ini menolak hipotesis karena terdapat pengaruh negatif yang signifikan antara financial target terhadap kecurangan pada laporan keuangan pada hasil penelitian.

Penyebab munculnya pengaruh negatif yang signifikan atas financial target yang diproksikan dengan ROA adalah pada dasarnya ROA merupakan gambaran kinerja perusahaan selama satu periode. Jika ROA pada tahun sebelumnya tinggi, maka dapat memacu perusahaan untuk meningkatkan kembali ROA dengan tujuan memperlihatkan kinerja yang meningkat sehingga perusahaan akan mendapatkan laba yang besar dari pengelolaan asset yang baik. Sedangkan untuk mendanai asset perusahaan, sumberdana diperoleh dari kegiatan penjualan saham karena harga saham memiliki keterkaitan dengan kondisi keuangan perusahaan. Saat laba yang diperoleh tinggi maka investor juga memiiki kepercayaan tinggi menyebabkan harga saham akan naik. Jika harga saham naik pembayaran deviden juga tinggi sehingga perusahaan tidak dapat melakukan kecurangan berupa manipulasi laba. Namun, jika $t_{\text {hitung }}>t_{\text {tabel }}$ yang menimbulkan pengaruh negative signifikan, ketika ROA semakin meningkat, akan menyebabkan kecurangan pada laporan keuangan. Wahyuni \& Budiwitjaksono (2017) menyebutkan bahwa manajemen tidak berminat melakukan fraud berupa manipulasi laba jika ROA rendah.

Hasil penelitian pada tabel 3 menunjukkan bahwa tingkat probabilitas yang terbentuk pada nature of industry dengan rasio piutang lebih besar daripada $\alpha 0,05$ yaitu sebesar 0,853 . Dalam tabel 2 pada hasil uji $\mathrm{T}$ menunjukkan bahwa $\mathrm{t}_{\text {hitung }} 0,187<\mathrm{t}_{\text {tabel }} 2,019$ Hasil tersebut menyatakan bahwa $\mathrm{H} 2$ ditolak dan dapat disimpulkan jika nature of industry yang diproksikan dengan rasio piutang (Receivable Ratio) berpengaruh tidak signifikan terhadap terjadinya kecurangan laporan keuangan. Hasil penelitian ini tidak sejalan dengan Faradiza (2018) yang memberikan sebuah hasil bahwa nature of industry yang diukur dengan menggunakan rasio perubahan piutang usaha memberikan dampak signifikan terhadap kecurangan laporan dalam keuangan.

Hasil penelitian ini menolak hipotesis karena penelitian ini membuktikan tidak ada pengaruh signifikan nature of industry terhadap kecurangan pada laporan keuangan. Karena banyaknya perusahaan-perusahaan melakukan pencadangan piutang tak tertagih sesuai dengan usia dan besaran piutang, sehingga kemungkinan untuk melakukan manipulasi terhadap pencadangan piutang sangat kecil, karena dalam mencadangkan akun piutang tak tertagih dilakukan secara subjektif yang berkaitan 
dengan besarannya.

Hasil penelitian pada tabel 3, menunjukkan bahwa tingkat probabilitas yang terbentuk pada quality of external auditor lebih besar daripada $\alpha$ 0,05 yaitu sebesar 0,797. Hasil uji T menunjukkan bahwa $\mathrm{t}_{\text {hitung }}-0,259<\mathrm{t}_{\text {tabel }}$ sebesar 2,019. Berdasarkan hasil tersebut, menyatakan bahwa H3 ditolak dan dapat disimpulkan jika quality of external auditor berpengaruh tidak signifikan terhadap terjadinya kecurangan laporan keuangan.

Sejalan dengan hasil penelitian Bawekes et al., (2018) yang menyebutkan bahwa kualitas auditor eskternal tidak memberikan pengaruh signifikan terhadap terjadinyan kecurangan laporan keuangan dan menolak hipotesis. Hal ini disebabkan auditor eksternal yang masuk dalam kategori KAP BIG 4 maupun KAP Non BIG 4 mempunyai peran yang setara atau sama dalam melakukan kegiatan audit laporan keuangan. Selain itu, peran auditor ekternal kategori KAP BIG 4 maupun Non BIG 4 juga menentukan kesalahan serta peluang p laporan keuangan terdapat salah saji material berdasarkan standar akuntansi yang berlaku umum. Semua auditor yang masuk dalam KAP BIG 4 maupun Non BIG 4 mempunyai posisi yang setara yaitu mematuhi peraturan standar auditing dalam melaksanakan tugasnya dan mendapatkan sanski jika melakukan pelanggaran.

Hasil penelitian pada tabel 3, menunjukkan bahwa tingkat probabilitas yang terbentuk pada change of auditor lebih kecil daripada a 0,05 yaitu sebesar 0,033. Hasil uji T menunjukkan bahwa $\mathrm{t}_{\text {hitung }} 2,205>\mathrm{t}_{\text {tabel }}$ 2,019. Hasil tersebut menyatakan bahwa $\mathrm{H} 4$ diterima dan dapat disimpulkan jika change of auditor berpengaruh signifikan terhadap terjadinya kecurangan laporan keuangan.

Hasil penelitian ini tidak sejalan dengan Septriyani \& Handayani, (2018) dan Pratiwi \& Nurbaiti (2018) yang belum menunjukkan hasil yang signifikan mengenai pengaruh pergantian auditor namun, menerima hipotesis yang menyatakan bahwa change of auditor berpengaruh signfikan terhadap kecurangan laporan keuangan.

Kurangnya efektifitas pengawasan dalam perusahaan menyebabkan munculnya potensi terjadinya kecurangan fraud. Kurangnya efektifitas pengawasan akan membuat manajemen merasa bebas dan leluasa dalam meningkatkan keuntungan dan kesejahteraan pribadinya. Selain itu, dengan adanya pergantian auditor akan menutupi kecurangan yang terjadi dalam laporan keuangan perusahaan karena lemahnya pengawasan.

Hasil penelitian pada tabel 3, menunjukkan bahwa tingkat probabilitas yang terbentuk pada change of direction lebih kecil daripada $\alpha 0,05$ yaitu sebesar 0,019 . Hasil uji $\mathrm{T}$ menunjukkan bahwa $\mathrm{t}_{\text {hitung }} 2,446>\mathrm{t}_{\text {tabel }}$ 2,019. Hasil tersebut menyatakan bahwa H5 diterima dan dapat disimpulkan jika change of direction berpengaruh signifikan terhadap terjadinya kecurangan laporan keuangan. Hasil penelitian ini tidak sejalan dengan hasil penelitian Elviani et al., (2020) dan sejalan dengan penelitian Bayagub et al., (2018). Dengan adanya perubahan direksi, dapat menimbulkan pengalihan tanggung jawab kepada direksi baru serta merahasiakan kecurangan direksi sebelumnya jika tidak dilakukan 
sesuai dengan ketentuan. Selain itu, pergantian direksi dapat menimbulkan indikasi kecurangan dalam laporan keuangan karena hal tersebut tidak akan terjadi jika seseorang tidak mempunyai kompetensi (capability).

Hasil penelitian pada tabel 3, menunjukkan bahwa tingkat probabilitas yang terbentuk pada CEO PIC lebih besar daripada $\alpha$ 0,05 yaitu sebesar 0,504. Hasil uji T menunjukkan bahwa thitung $-0,675<$ ttabel 2,019. Hasil tersebut menyatakan bahwa H6 ditolak dan dapat disimpulkan jika CEO PIC berpengaruh tidak signifikan terhadap terjadinya kecurangan laporan keuangan. Hasil penelitian ini tidak sejalan dengan hasil penelitian R. Siddiq et al., (2017) yang menyatakan bahwa jumlah foto CEO (Frequent Number of CEO) tidak memberikan pengaruh signifikan terhadap terjadinya kecurangan laporan keuangan.

Hasil penelitian ini menolak hipotesis yang menyatakan bahwa Frequent Number Of CEO berpengaruh signfikan terhadap kecurangan laporan keuangan. Karena adanya foto CEO dalam laporan keuangan bertujuan untuk memperkenalkan kepada para stakeholders atau pengguna laporan keuangan siapa saja CEO dalam perusahaan tersebut. Selain itu, tujuan adanya foto CEO dalam laporan keuangan adalah menampilkan kegiatan dan prestasi yang diperoleh perusahaan yang membuktikan bahwa CEO turut andil dalam kegiatan perusahaan tersebut. Sehingga, para pengguna laporan keuangan dan masyarakat umum dapat menilai tanggung jawab dan keuletan CEO dalam memimpin perusahaan.

\section{KESIMPULAN DAN SARAN}

Berdasarkan hasil analisis dan pengujian hipotesis, kesimpulan dari penelitian ini adalah Financial Target berpengaruh tidak signifikan terhadap terjadinya kecurangan laporan keuangan. Nature of Industry berpengaruh tidak signifikan terhadap terjadinya kecurangan laporan keuangan. Quality of External Auditor berpengaruh tidak signifikan terhadap terjadinya kecurangan laporan keuangan. Change of Auditor berpengaruh signifikan terhadap terjadinya kecurangan laporan keuangan. Change of Direction berpengaruh signifikan terhadap terjadinya kecurangan laporan keuangan. Frequent Number of CEO berpengaruh tidak signifikan terhadap terjadinya kecurangan laporan keuangan. Change of Auditor berpengaruh signifikan terhadap terjadinya kecurangan dalam laporan keuangan. Sebagai proksi dari variabel rasionalisasi (rationalization), pergantian auditor dapat mendorong terjadinya kecurangan laporan keuangan karena manajemen merasa bebas dan leluasa dalam meningkatkan keuntungan dan kesejahteraan pribadinya disebabkan kurangnya pengawasan. Jika perusahaan sering mengganti auditor dapat memperkecil deteksi fraud dalam laporan keuangan, karena meninjau perusahaan dan laporan keuangannya memerlukan waktu lebih panjang bagi auditor baru. Change of Direction berpengaruh signifikan terhadap terjadinya kecurangan laporan keuangan. Sebagai proksi dari elemen kompetensi (capability) dari fraud pentagon, pergantian direksi dapat 
mendorong terjadinya kecurangan laporan keuangan karena dengan adanya direksi baru, akan menutupi kesalahan direksi sebelumnya dan pengalihan tanggung jawab. Selain itu, adanya pergantian direksi dapat menyebabkan adanya praktik kecurangan laporan keuangan dengan.

Masukan bagi pengendali internal untuk pertimbangan penilaian kinerja perusahaan bisa didapatkan dari hasil penelitian ini. Setelah dibuktikan dalam penelitian ini, rasionalisasi (rationalization) dan kompetensi (capability) dapat berpengaruh terhadap terjadinya kecurangan. Dengan proksi perubahan change of auditor untuk rationalization dan change of direction untuk capability yang dapat dipergunakan untuk pendeteksian kecurangan pada laporan keuangan. Hasil dari penelitian dapat digunakan oleh para pemangku kepentingan atau stakeholder untuk bahan pertimbangan dalam pengambilan keputusan agar lebih tepat dan waspada dalam mengambil keputusan. Jadi, keputusan yang diambil tidak merugikan dimasa yang akan datang dikarenakan kesalahan pengambilan keputusan karena adanya kecurangan laporan dalam keuangan. Keterbatasan dalam penelitian ini adalah variabel yang digunakan serta pemilihan proksi pada penelitian ini terbatas untuk mendeteksi adanya kecurangan laporan keuangan. Lalu kurangnya gambaran mengenai kondisi perusahaan industry secara keseluruhan karena hanya menggunakan 1 jenis sektor yang listed di BEI yaitu sektor manufaktur. Selanjutnya penelitian hanya dilakukan selama tahun 2017 hingga 2019. Dari adanya keterbatasan penelitian tersebut, maka penulis menyarankan untuk pengembangan penelitian selanjutnya diharapkan menggunakan variabel dan mengembangkan proksi lain dari fraud pentagon agar menghasilkan data dan model pendeteksian kecurangan laporan keuangan yang lebih akurat. Penelitian selanjutnya diharapkan menggunakan sektor lain seperti sektor perbankan dan sektor pemerintahan dimana sering terdapat praktik fraud agar jangkauan lingkup penelitian menjadi lebih luas. Penelitian selanjutnya juga diharapkan dapat menambahkan rentang waktu dalam pengamatan supaya mendapatkan hasil yang lebih terkini.

\section{DAFTAR PUSTAKA}

Agusputri, H., \& Sofie, S. (2019). Faktor - Faktor Yang Berpengaruh Terhadap Fraudulent Financial Reporting Dengan Menggunakan Analisis Fraud Pentagon. Jurnal Informasi, Perpajakan, Akuntansi, Dan Keuangan Publik, Vol. 14 (No. 2), Hal 105-124. https://doi.org/10.25105/jipak.v14i2.5049

Agustina, R. D., \& Pratomo, D. (2019). Pengaruh Fraud Pentagon Dalam Mendeteksi Kecurangan Pelaporan Keuangan. Jurnal Ilmiah Manajemen, Ekonomi, \& Akuntansi (MEA), Vol. 3 (No. 1), Hal 44-62. https://doi.org/10.31955/mea.vol3.iss1.pp44-62

Annisya, M., Lindrianasari, \& Asmaranti, Y. (2016). Pendeteksian Kecurangan Laporan Keuangan Menggunakan Fraud Diamond. Jurnal Bisnis Dan Ekonomi (JBE), Vol. 23(No. 1), Hal. 72-89. 
Aprilia, A. (2017). Analisis Pengaruh Fraud Pentagon Terhadap Kecurangan Laporan Keuangan Menggunakan Beneish Model Pada Perusahaan Yang Menerapkan Asean Corporate Governance Scorecard. Jurnal ASET (Akuntansi Riset), Vol. 9 (No. 1), Hal 101. https://doi.org/10.17509/jaset.v9i1.5259

Bawekes, H. F., Simanjuntak, A. M. A., \& Daat, S. C. (2018). Pengujian Teori Fraud Pentagon Terhadap Fraudulent Financial Reporting (Studi Empiris pada Perusahaan yang Terdaftar di Bursa Efek Indonesia Tahun 2011-2015). Jurnal Akuntansi \& Keuangan Daerah, Vol. 13 (No. 1), Hal 114-134.

Bayagub, A., Zulfa, K., \& Mustoffa, A. F. (2018). Analisis Elemen-Elemen Fraud Pentagon Sebagai Determinan Fraudulent Financial Reporting (Studi Pada Perusahaan Property dan Real Estate Yang Terdaftar Di Bursa Efek Indonesia Periode 2014-2016). ISOQUANT : Jurnal Ekonomi, Manajemen Dan Akuntansi, Vol. 2 (No. 1), Hal 1-11. https://doi.org/10.24269/iso.v2i2.184

Crowe, H. (2010). IIA Practice Guide: Fraud and Internal Audi. United States Of America.

Elviani, D., Ali, S., \& Kurniawan, R. (2020). Pengaruh Kecurangan Laporan Keuangan terhadap Nilai Perusahaan: Ditinjau dari Perspektif Fraud Pentagon (Kasus di Indonesia). Jurnal Ilmiah Universitas Batanghari Jambi, Vol. 20 (No. 1), Hal 121-125. https://doi.org/10.33087/jiubj.v20i1.828

Faradiza, S. A. (2018). Fraud Pentagon Dan Kecurangan Laporan Keuangan. EkBis: Jurnal Ekonomi Dan Bisnis, Vol. 2 (No. 1), Hal 1-22. https://doi.org/10.14421/ekbis.2018.2.1.1060

Hery. (2016). Analisis Laporan Keuangan. Penerbit Gramedia Widiasarana Indonesia.

Lestari, M. I., \& Henny, D. (2019). Pengaruh Fraud Pentagon Terhadap Fraudulent Financial Statements Pada Perusahaan Perbankan Yang Terdaftar Di Bursa Efek Indonesia Tahun 20152017. Jurnal Akuntansi Trisakti, Vol. 6 (No. 1), Hal 141-156. https://doi.org/10.25105/jat.v6i1.5274

Pratiwi, N. R., \& Nurbaiti, A. (2018). Analisis Fraud Pentagon Dalam Mendeteksi Kecurangan Laporan Keuangan Dengan Metode F-Score Model (Studi Empiris Pada Perusahaan Pertambangan Yang Terdaftar Di Bursa Efek Indonesia (BEI) PERIODE 2012-2016). EProceeding of Management, Vol. 5 (No. 3), 3299.

Priantara, D. (2013). Fraud Auditing \& Investigation. Penerbit Mitra Wacana Media.

Sasongko, N., \& Wijayantika, S. F. (2019). Faktor Resiko Fraud Terhadap Pelaksanaan Fraudulent Financial Reporting (Berdasarkan Pendekatan Crown'S Fraud Pentagon Theory). Riset Akuntansi Dan Keuangan Indonesia, Vol. 4 (No. 1), Hal 67-76. https://doi.org/10.23917/reaksi.v4i1.7809

Septriyani, Y., \& Handayani, D. (2018). Mendeteksi Kecurangan Laporan Keuangan dengan Analisis Fraud Pentagon. Jurnal Akuntansi, Keuangan Dan Bisnis, Vol. 11 (No. 1), Hal 11-23. http://jurnal.pcr.ac.id 
Setiawati, E., \& Baningrum, R. M. (2018). Deteksi Fraudulent Financial Reporting Menggunakan Analisis Fraud Pentagon: Studi Kasus Pada Perusahaan Manufaktur Yang Listed Di Bei Tahun 2014-2016. Riset Akuntansi Dan Keuangan Indonesia, Vol. 3 (No. 2), Hal 91-106. https://doi.org/10.23917/reaksi.v3i2.6645

Siddiq, F. R., \& Suseno, A. E. (2019). Fraud Pentagon Theory Dalam Financial Statement Fraud Pada Perusahaan Terdaftar di Jakarta Islamic Index (JII) Periode 2014-2017 (Perspektif F-Score Model). Jurnal Nusantara Aplikasi Manajemen Bisnis, Vol. 4 (No. 2), Hal 128-138. https://doi.org/10.29407/nusamba.v4i2.13800

Siddiq, R., Achyani, F., \& Zulfikar. (2017). Fraud Pentagon Dalam Mendeteksi Financial Statement. Peran Profesi Akuntansi Dalam Penanggulangan Korupsi, ISSN 2460-0784, Hal 1-14. http://hdl.handle.net/11617/9210

Sugiyono. (2017). Metode Penelitian Kuantitatif, Kualitatif, dan R\&D. Penerbit Alfabeta.

Tessa, C., \& Harto, P. (2016). Pengujian Teori Fraud Pentagon Pada Sektor Keuangan Dan Perbankan Di Indonesia. Simposium Nasional Akuntansi XIX Lampung, 1-21. file://C:/Users/ASUS/Downloads/Pengujian Teori Fraud Pentagon Pada Sektor Keuangan dan Perbankan di Indonesia.pdf

Wahyuni, W., \& Budiwitjaksono, G. S. (2017). Fraud Triangle Sebagai Pendeteksi Kecurangan Laporan Keuangan. Jurnal Akuntansi, Vol. 21 (No. 1), Hal. 47. https://doi.org/10.24912/ja.v21i1.133 